\title{
A Radical Reinterpretation of Quinean Naturalism and Its View of Consciousness
}

\author{
PAMELA ANN J. BOONGALING \\ Department of Philosophy, University of the Philippines, Diliman, Quezon City, Philippines \\ Email: pamelaannnjose@gmail.com; pamela_ann.jose@upd.edu.ph
}

\begin{abstract}
McGinn maintains that Quinean naturalism cannot provide a viable position in the debate on the existence of consciousness and the external world for it does not have a place for phenomenal experience in its naturalized epistemology. In effect, it cannot or will refuse to address any version of a sceptic's argument regarding the lack of sufficient grounds to prove the existence of consciousness and the external world. I argue otherwise by pointing out that Quinean naturalism must provide an account of phenomenal experience to ensure the consistency of its epistemic and ontic assumptions with its naturalistic worldview. In the process, I demonstrate that Quinean naturalism allows us to infer that the best explanation for the existence of both consciousness and the external world can be derived from how the roles of subjectivity and objectivity in our creation and assessment of our conceptual schemes are primarily derived from our phenomenal experience of the external world.
\end{abstract}

Keywords: Quine, McGinn, scepticism, naturalism, physicalism, consciousness, scientific mysterianism

\section{INTRODUCTION}

Colin McGinn $(1996,2011,2015,2017)$ claims that Quinean naturalism (henceforth QN) cannot provide a viable position in the debate on the existence of consciousness and the external world for it does not have a place for phenomenal experience in its naturalized epistemology. Such a position is unwarranted for it is based on a very limited interpretation of QN. Within this context, I will show that a reinterpretation of QN can accommodate consciousness understood as phenomenal experience that is not purely reducible to brain states. I will also demonstrate that QN can also provide a viable solution to the sceptic's argument for our inability to provide sufficient grounds to prove the existence of both consciousness and the external world.

This discussion is of import since, even if at face value, these claims seem to be contrary to Quine's (1971) view that sceptical arguments regarding the existence of the external world are irrefutable yet irrelevant, I will show that his version of externalism must refute a version of the sceptic's argument in order to ensure the consistency of its epistemic and ontic assumptions with its naturalistic worldview. I will also show that QN can refute this version of the sceptic's argument only if it changes the underlying presumption of its physicalism and if it allows the reintroduction of the a priori/a posteriori distinction in its epistemology. 
To begin with, it is important to situate Quine's place in analytic philosophy. He is primarily known for dissolving the analytic/synthetic distinction and for rejecting empirical reductionism (Quine 1951; Soames 2017; Smith 2019). Along with these, he initiated the contemporary project of naturalizing epistemology (Quine 1951; Soames 2017; Smith 2019). Now, QN is typically described in terms of its adherence to two theses. First, it prescribes that we should look to science, especially to those statements that are best confirmed in our most expedient scientific theories, for the bases of our epistemic justifications (i.e. naturalism) (Leng 2010). Second, it maintains that the confirmation of a scientific theory extends to the confirmation of the truth of all the statements within it (i.e. confirmational holism) (Leng 2010). Roger Gibson (2000), however, notes that in order to have a more robust understanding of QN, we should place these two theses side by side with QN's empiricist and physicalist views. He states:

'Empiricism is Quine's epistemology, his theory of method and evidence; physicalism is Quine's ontology, his theory of what there is. Since empiricism is a tentative finding of current science, and physicalism is a tentative hypothesis of current science, both Quine's current epistemology and his current ontology might in the long run turn out to be false. However, it is important to realize that the falseness of empiricism and of physicalism does not entail the falseness of naturalism...(S)cience may continue to provide the best (now non-empiricist) epistemology and best (now non-physicalist) ontology'. (Gibson 2000: 19-20)

As we can see, Gibson's description of QN above already provides us with a framework for assessing it since it shows us that if we wish to reinterpret QN, we can either focus on its epistemology, ontology, or both. Gibson's description of QN also tells us that any reinterpretation of QN should retain the rationale behind Quine's attempt to create a naturalized epistemology. So long as we refrain from readopting the traditional foundationalist attempts to find a bedrock for human knowledge that is based on a priori conceptual criteria and retain philosophy's partnership with science (e.g. cognitive psychology), we can still uphold QN's goal of looking to science to determine what we ought to believe. In other words, for a position to still count as a version of QN, it must always ensure the retention of QN's naturalist component.

With these in mind, what follows is McGinn's (1996) formulation of a sceptical argument against external realism. As I see it, this argument shows that there is a problem with QN's epistemic and ontic assumptions. To demonstrate this, let us first provide a formulation of McGinn's (1996) sceptical argument below:

(P1) Externalism presupposes that there is a mind-independent world.

(P2) Externalism also presupposes that consciousness is logically bound (i.e. inherently bound) with this mind-independent world.

(P3) Part of why consciousness is inherently bound with the external world is due to how it dictates how we can access the external world.

(P4) Since (P3), the content of our perceptual states is determined by the relationship between consciousness and its physical objects.

(P5) Since (P2) to (P4), how we know our consciousness is partially based on how we see its functions.

(P6) (P1) and (P5) show that we cannot fully know consciousness for to do so requires situating it as an object within the external world.

(P7) If (P6), we cannot fully determine the deductive link between consciousness and its objects. 
(C) If (P7), we have insufficient grounds to prove the existence of both consciousness and the external world.

This poses a problem for QN for, as McGinn $(1996,2015)$ claims, the sceptic requires it to provide definitive grounds to support the existence and the causal relation of consciousness and its objects. We may initially respond to McGinn by claiming that Quine (1971) will simply shrug this off for even if he stated that sceptical arguments are irrefutable and irrelevant, he also claimed that if we really wish to address sceptical problems regarding the existence of the external world, we should phrase them as scientific problems. Furthermore, we may also emphasize that physicalism is merely a hypothesis in science hence it is open to revision. However, these claims cannot offset the force of McGinn's sceptical argument above for (P5) and (P6) show that physicalism cannot be based on the view that we directly perceive the objects in the external world.

If we look at Quine's description of how we assess stimuli in the boundary conditions of science, we can consistently state that his physicalism presumes direct realism. We can derive this from his claims below:

'The totality of our so-called knowledge or belief...is a man-made fabric which impinges on experience along the edges. Or, to change the figure, total science is like a field of force whose boundary conditions are experience. A conflict with experience at the periphery occasions readjustment in the interior of the field... But the total field is so undetermined by its boundary conditions, experience, that there is much latitude of choice as to what statements to re-evaluate in the light of any single contrary experience.' (Quine 1951: 41-42)

His physicalism, in this context, is based on the presumption that we can directly perceive the objects in the external world since he describes the peripheries of science as a place where experience is a byproduct of our actual contact with the external world. As he claims above, the 'periphery' of science's 'field of force' uses experience as its boundary conditions (Quine 1951). Experience, in this context, is not yet fully encapsulated with the conceptual scheme of science. It is, at this stage, an event that allows the connection between our conceptual scheme and what it attempts to represent. Now, since Quine's physicalism presumes direct realism, it must also presuppose that there is a subjective component to consciousness for we cannot arrive at direct realism from a purely objective characterization of consciousness. Due to this, QN cannot escape and should address the formulation of the sceptic's argument above if it wishes to ensure the consistency of its epistemic and metaphysical claims.

At this point, I will attempt to save QN by refuting (P6) even if I will adopt (P1)-(P6) of McGinn's formulation of the sceptic's argument above. As I see it, the problem with the sceptic's argument lies in its negative interpretation of (P6). As an aside, it should be noted that I recognize that McGinn $(1996,2011,2015,2017)$ himself attempts to address the sceptic's argument above through his scientific mysterianism. His argument denies the physicalists' tendency to deflate consciousness by denying that mental states can be reduced to either behavioural states or physical states yet he uses the physicalists' emphasis on our physiological traits to argue that we cannot fully know both consciousness and intentionality since we have limited cognitive and hence epistemic access to them (McGinn 1996, 2011, 2015, 2017). However, as I see it, the problem with McGinn's position is that scientific mysterianism supports (P6) of the sceptic's argument above. In effect, even if McGinn claims that it is reasonable to assume that consciousness exists, his view about consciousness can prove the contrary in the sceptic's hands. Within this context, our focus on the next section will be on a reinterpretation of QN that can address the sceptic's challenge to Quine's physicalism and empiricism. 


\section{A RADICAL REINTERPRETATION OF QUINEAN NATURALISM}

In this section, I will provide a reinterpretation of QN that can accommodate both the phenomenal and non-phenomenal aspects of consciousness. This reinterpretation is radical in so far as I will demonstrate that (1) direct realism can be retained as an underlying assumption of QN's physicalism only if it accommodates the role of intentionality in the non-phenomenal state of consciousness and (2) physicalism can only be retained in QN if its epistemology accommodates the a priori/a posteriori distinction. In addition to these, I will also show that (3) a QN view that espouses (1) and (2) can provide us with a sufficient basis for the existence of consciousness contrary to the sceptical argument in the prior section.

To establish (1) and (2), let us begin by providing an example of how our consciousness allows us to access the external world. When I look outside my window, my eyes receive various stimuli. In effect, I sense various objects outside my window. My vision may then be directed to the dark spots on the leaves of a mango tree. At that moment when my vision has been directed to those leaves, I am already perceiving them since my vision already has an object. At that moment, we can also say that I have adopted a propositional attitude about an object (i.e. I believe that there are dark spots on the leaves of the mango tree). After seeing these dark spots, I may feel irritation towards myself since I forgot to purchase the insecticide that will eradicate the insects causing those spots. I may also feel motivated to purchase and spray the insecticide the following day so as not to worsen the infestation. In these scenarios, I have adopted propositional attitudes. The attitude in the former is an affective one since I am expressing an emotion which is directed towards myself. The latter, on the other hand, is a conative one since I am expressing how I will act given the circumstances.

The above-mentioned example is useful since it shows that consciousness can be directed to an object in the external world (e.g. the dark spots on the leaves) and towards oneself (e.g. feeling irritation towards one's self and being motivated to act on these feelings). That is to say, the hallmark of consciousness is its capacity for intentionality. That is, its capability to enable its bearer to direct and give meaning to the object of its awareness. With these in mind, I am supplying a very broad characterization of consciousness in this paper. To be conscious is to be in a state of awareness which is capable of intentionality. Giving these minimal conditions for a conscious state is not remiss for at least two reasons. First, it considers how our access and representations of the external world are derived from both our subjective (i.e. first-person) and objective (i.e. third-person) access to conscious states. Second, it is open to a cogent position that may establish the connection between our conscious states and the external world. Both of these will allow us to establish (1) to (3) above.

At this point, it is crucial to take note of how I characterize an intentional state. As I see it, an intentional state can be understood in terms of two levels. In the first level, an intentional state is non-conceptual in character for it merely requires us to direct our awareness to an object. In this sense, we can say that we are naturally predisposed to be in an intentional state since our physiological make-up allows us to sense the objects in our environment. In other words, our physiological make-up allows us to be aware of the existence of objects in space because we ourselves are situated in space and we are in a position to perceive these objects during a particular time-frame. To give a more specific example, our eyes have naturally evolved to receive specific kinds of stimuli from our surroundings. Our visual sensations, however, only start to have intentional content when we direct our eyes to a particular object in our environment. Now, it may be the case that our visual cortex is completely damaged. In this scenario, our visual sensations cannot have intentional content for our visual system cannot process 
the stimuli due to the defect in our visual cortex. In a similar manner, our visual system may be compromised due to an imbalance in our neurochemistry. If this imbalance leads us to believe that we are perceiving an object that does not exist, as is the case in hallucinations, our visual sensation cannot be said to have intentional content since it does not have an object.

Whereas the first level of an intentional state is non-conceptual in character, the second level involves conceptual representation. In this level, we can discriminate between the objects of our awareness because we make use of a conceptual scheme. We can discriminate between viridian, turquoise and mint because we have acquired the concepts for these shades of green (and for the concept of green as well). Conceptual representation imbues meaning to our experiences. For instance, we can say that there may be something lacking in Angus' appreciation of a painting if he is unable to recognize how an artist used the aforementioned shades of green to set the mood in his work. As you can see, representation in the second level of an intentional state is more complex for it requires immersion and continuous participation in a language game. It is at this level of an intentional state then that we can accommodate how Quine (1960) describes the role of language in allowing us to translate our experiences into observation statements and later on into theoretical statements.

Now, these two modes of presentation of perceptual experiences are important in showing us that the existence of consciousness is a pre-requisite for direct realism in so far as they allow us to show that how consciousness accesses the world in the non-conceptual level of an intentional state already gives us a position of objectivity. It is able to do so for it involves a subjective recognition of one's separation from the objects in the external world. Recall that in our example earlier (e.g. seeing the dark spots on a leaf), we immediately recognize our separation from the object of our perception via the difference of our position in space and time. In this sense, we can see that QN's physicalism can only work if it allows the introduction of the first level of an intentional state for it is only in this level that its presupposition of direct realism can explain how we can have experiences at the peripheries of science.

What is more interesting about this initial level of our intentional state is how it gives us our initial access to an objective standpoint that later on allows us to create conceptual schemes and to practice degrees of subjectivity and objectivity towards our assessment of our conceptual schemes. In effect, I am stating that the objective, third person point of view given to us by our scientific theories are derived from the subjective, first person point of view that our non-phenomenal mental states possess in our initial perception of the external world. That QN itself implicitly works under a similar presumption is evident if we see how it envisions the normative component of its naturalized epistemology.

Quine claims that the normative component of his naturalized epistemology is 'a branch of engineering', 'the technology of truth-seeking' and 'a matter of efficacy for an ulterior end, truth' (Quine 1986: 664-5). In this view, the normative component of QN lies in the role of utility in decision making. In effect, how we choose the theories that best describe our experiences are reliant on the utility of these theories' descriptions of the external world. There is the presumption that so long as a theory best describes natural phenomena then it is a useful theory whose ontic and epistemic assumptions can be used to determine what we should presume to exist and what we should presume to be true. Yet, even if Quine situates how truth-conditions and existence claims are learned and determined within a conceptual scheme, his emphasis on the role of QN as a means to arrive at truth also shows us its inherent presumption of the phenomenal aspect of consciousness. This is implicitly recognized by Bas van Fraassen (2008) when he maintains that if we prioritize utility in the assessment of 
a scientific theory, we are immediately forced to presuppose the existence of a conscious agent who determines what counts as useful. Such a presupposition, however, cannot coincide with a mere characterization of consciousness as a phenomenal mental state for it involves the presupposition that consciousness has an innate agency to it. If we look at our how the initial level of an intentional state allows us to direct our senses to an object, we can see this innate agency at work in the non-phenomenal state of awareness.

Some may say that this view runs contrary to Quine's position since he may claim that even if science adopts certain ontic assumptions (e.g. consciousness is purely material in nature), the utility and success of science provides sufficient evidential grounds for these ontic assumptions. In effect, science can supply sufficient grounds for the presupposition that consciousness as a non-phenomenal state must exist in order for us to arrive at physicalism's hypothesis that there is an external world. To show the problem with this view, we need to show that it is not always the case that practical grounds provide evidential grounds for the existence of an object. In this case, we only need to show that not all statements in scientific theories are literally true. There are occasions, for example, when we make use of idealizations (e.g. Boyle's law). In these occasions, we assume that an object exists (e.g. ideal gas) in order to describe observable phenomena. If some scientific statements are presumed to be true even if we know that they are mere idealizations, then it follows that practical purposes do not always provide evidential grounds for the existence of an object. In other words, just because it is practical for us to assume that non-phenomenal consciousness and the external world exist do not necessarily mean that they exist. To prove their existence, we must resort to a different method.

At this point, some may resort to the confirmational holism thesis I mentioned in the previous section. They may claim that in QN, when it comes to statements that are not idealizations in science, we should consider such statements to be true since the effectiveness of our theories' predictive capacities about natural phenomena should be sufficient to establish the ontological existence of the objects in the statements of our best scientific theories. In this view, they can say that our presupposition that non-phenomenal consciousness exists is already supported by theories that show that there must be a correlation and/or causal connection between conscious states and brain states.

There are at least two problems that can be raised against this view. The first is a weak one since it simply points out, what Gibson mentioned earlier, that both empiricism and physicalism may be discarded if we have sufficient grounds to do so. It is a weak problem since it may be stated that the scientific enterprise continues to expand, and its history has shown that it has solved what were once considered puzzling phenomena. The second problem is a hard one though. Science works on the assumption that its theories are purely a posteriori in character. However, such is not the case.

Nicholas Maxwell (2011) notes that scientific knowledge is a priori in character in so far as it makes a crucial conjecture about the external world. To offset any misunderstandings, he notes that a priori knowledge as he sees it does not pertain to indubitable knowledge but merely the conjectural kind. He also maintains that there is only one kind of a priori knowledge in science, which is the claim that there must be unity in nature. This is not difficult to see since we know that physics currently aims for a unified theory of everything and in practice, theories are only accepted provisionally (e.g. so long as they are consistent with the best theory of a particular time). Following Maxwell's view leads us to the claim that if the overarching theory of science rests on this a priori assumption, then it follows that we cannot fully provide 
a posteriori grounds for our ontological claims. In effect, we cannot fully characterize consciousness on purely a posteriori grounds.

Before we proceed, I would like to point out that we have already established the first two goals of this section. We have shown that QN can only retain its version of physicalism so long as it accommodates non-phenomenal mental states. Such is the case for physicalism's basis (i.e. direct realism) can only be consistently maintained in QN if it incorporates the first level of an intentional state that we mentioned earlier. We have also shown that if QN does not accommodate non-phenomenal experience, it cannot retain its methodology's emphasis on a scientific theory's utility. In addition, we have demonstrated that even QN's empiricism is riddled by the problem of its refusal to acknowledge the a priori/a posteriori distinction.

Within this context, we can proceed to demonstrate our third goal in this section. If QN adopts our characterization of intentional states and their relationship to non-phenomenal and phenomenal experience, we can provide a sufficient basis for the existence of consciousness contrary to the sceptical argument in the previous section. Such is the case for QN can now show that (P1) to (P6) of the sceptic's argument above do not necessarily lead to scepticism about the existence of consciousness and the external world. If consciousness and the external world is inherently bound with one another, then it must be the case that there is an actual external world for if the degrees of objectivity that is made available to us by our consciousness is initially based on our mental state that has non-intentional content, then, as I've mentioned earlier, that state must already provide an initial ground for objectivity. That is, it already provides an initial setting wherein our consciousness is separate from an object. If such is the case, then the function of consciousness provides sufficient grounds for its existence. In effect, even if we cannot fully establish the deductive link that the sceptic desires between consciousness and the external world, an inference to the best explanation via the functions of consciousness would be sufficient to prove its existence as well as the existence of the external world.

\section{CONCLUSIONS}

In our discussion, I have provided a reinterpretation of QN that shows that if it aims to retain its empiricist, physicalist and naturalist views, it must recognize that the conjunction of these views requires it to modify its conception of consciousness as mere phenomenal experience. In doing so, I introduced a distinction between non-phenomenal and phenomenal consciousness that is able to retain the subjective component of the former and the objective component of the latter. This was made possible as I emphasized the difference of the role of intentionality in non-phenomenal and phenomenal mental states. Although my reformulation of QN involves changes to its physicalist and empiricist views, I was able to maintain its naturalist leanings partly by emphasizing that the method of science (i.e. inference to the best explanation) enables us to arrive at a sufficient proof for the existence of consciousness and the external world. All of these combined allowed us to counter the sceptical argument in the initial part of this paper.

It should be noted that this formulation of QN escapes what Brock and Mares (2007) consider to be an inherent inconsistency in this version of realism about the external world. They maintain that realism of this kind leads to the view that our knowledge of the external world will always be mind-dependent since it should be based on a proper relationship between our mind and its objects (Brock, Mares 2007). Our position, however, does not lead 
to this inconsistency. To say that a mental state is mind-dependent is only problematic if we cannot confirm the correspondence between our mental content and the state of affairs in the external world. Even if how we derive this content is based on our cognitive and physiological limitations, our mind is able to arrive at the mental content since its framework allows it to capture the framework of the external world. The initial level of our intentional state, for example, allows us to capture the spatiotemporal existence of the objects in the external world. The second level of our intentional state, on the other hand, enables us to create a language (e.g. set theoretic model) that allows us to check our mathematical representations of the external world. It is also within this context that I find QN attractive. If it accommodates the a priori/a posteriori distinction, we can have a better grasp of how the mathematical structure of our scientific theories conforms to the structure of the world.

Received 15 October 2018 Accepted 20 May 2019

\section{References}

1. Brock, S.; Mares, E. 2007. Realism and Anti-Realism. Durham: Acumen.

2. Gibson, R. 2000. 'The Key to Interpreting Quine', in Philosophy of Quine: General, Reviews, and Analytic/ Synthetic, ed. D. Føllesdal. New York: Garland Publishing, 25-38.

3. Leng, M. 2010. Mathematics and Reality. Oxford: Oxford University Press.

4. Maxwell, N. 2011. 'A Priori Conjectural Knowledge in Physics: The Comprehensibility of the Universe', in What Place for the A Priori?, eds. M. Shaffer and M. Veber. La Salle: Open Court, 211-240.

5. McGinn, C. 1996. The Character of Mind: An Introduction to the Philosophy of Mind. Oxford: Oxford University Press, 176.

6. McGinn, C. 2011. Basic Structures of Reality: Essays in Meta-Physics. Oxford: Oxford University Press.

7. McGinn, C. 2015. Inborn Knowledge: The Mystery Within. Cambridge: MIT Press.

8. McGinn, C. 2017. Philosophical Provocations. Cambridge: MIT Press.

9. Quine, W. V. O. 1951. 'Dogmas of Empiricism', The Philosophical Review 60: 20-43.

10. Quine, W. V. O. 1960. Word and Object. Massachusetts: Massachusetts Institute of Technology Press.

11. Quine, W. V. O. 1971. Ontological Relativity and Other Essays. New York: Columbia University Press.

12. Quine, W. V. O. 1986. 'Reply to White', in The Philosophy of W. V. Quine, eds. L. Hahn and P. Schillp. La Salle: Open Court, 663-665.

13. Smith, J. A. 2019. 'Quine on Naturalism, Nominalism, and Philosophy's Place within Science', Synthese: 1-19.

14. Soames, S. 2017. 'The Changing Role of Language in Analytic Philosophy', in Analytic Philosophy: An Interpretive History, ed. A. Preston. London: Routledge, np.

15. Van Fraassen, B. 2008. Scientific Representation: Paradoxes of Perspective. Oxford: Oxford University Press. 
PAMELA ANN J. BOONGALING

\title{
W. V. O. Quine'o natūralizmo radikali reinterpretacija ir jo požiūris ị sąmonę
}

\begin{abstract}
Santrauka
C. McGinn’as tvirtina, kad W. V. O. Quine’o natūralizmas negali pateikti aiškios pozicijos diskusijoje apie sąmonès ir išorinio pasaulio egzistavimą, nes jis neskiria dèmesio fenomenaliajai patirčiai savo taikomojoje epistemologijoje. Todèl jis negali ar atsisako pateikti bet kokią skeptiškojo argumento versiją remdamasis tuo, kad nepakanka faktų įrodyti sąmonès ir išorinio pasaulio buvimą. Straipsnyje tvirtinama priešingai: filosofo natūralizmas privalo pateikti fenomenaliosios patirties aiškinimą, kad užtikrintų savo episteminių ir ontinių prielaidų neprieštaringumą ir savo natūralistinę pasaulèžiūrą. Nuosekliai parodoma, kad W. V. O. Quine’o natūralizmas leidžia daryti išvadą, jog tiek sąmonès, tiek išorinio pasaulio buvimas gali būti paaiškinamas tuo, kad subjektyvumo ir objektyvumo vaidmenys mūsų kūryboje ir konceptualinių schemų vertinimas pirmiausia kyla iš išorinio pasaulio fenomenaliosios patirties.
\end{abstract}

Raktažodžiai: Quine’as, McGinn’as, skepticizmas, natūralizmas, fizikalizmas, sąmonè, mokslinis misterizmas 